\title{
TAX COMPETITION AND MIGRATION: THE RACE-TO-THE-BOTTOM HYPOTHESIS REVISITED
}

\author{
Assaf Razin \\ Efraim Sadka \\ Working Paper 16670 \\ http://www.nber.org/papers/w16670
NATIONAL BUREAU OF ECONOMIC RESEARCH
1050 Massachusetts Avenue
Cambridge, MA 02138
January 2011

The views expressed herein are those of the authors and do not necessarily reflect the views of the National Bureau of Economic Research.

NBER working papers are circulated for discussion and comment purposes. They have not been peerreviewed or been subject to the review by the NBER Board of Directors that accompanies official NBER publications.

(C) 2011 by Assaf Razin and Efraim Sadka. All rights reserved. Short sections of text, not to exceed two paragraphs, may be quoted without explicit permission provided that full credit, including $\odot$ notice, is given to the source. 
Tax Competition and Migration: The Race-to-the-Bottom Hypothesis Revisited

Assaf Razin and Efraim Sadka

NBER Working Paper No. 16670

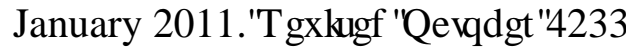

JEL No. F2,H2

\begin{abstract}
$\underline{\text { ABSTRACT }}$
Oates reminds us that tax competition among localities in the presence of capital mobility, may lead to inefficiently low tax rates (and benefits). In contrast, the Tiebout paradigm suggests that tax competition yields an efficient outcome, so that there are no gains from tax coordination. This paper demonstrates that when a group of host countries faces an upward supply of migrants, labor and capital income tax rate under competition are higher than under tax coordination, due to a fiscal externality.
\end{abstract}

\author{
Assaf Razin \\ Department of Economics \\ Cornell University \\ Uris 422 \\ Ithaca, NY 14853 \\ and Cornell University \\ and also NBER \\ ar256@cornell.edu \\ Efraim Sadka \\ Tel Aviv University \\ Eitan Berglas School of Economics \\ P.O.B. 39040 \\ Ramat Aviv, Tel Aviv, 69978, ISRAEL \\ sadka@post.tau.ac.il
}




\title{
TAX COMPETITION AND MIGRATION: THE RACE-TO-THE-BOTTOM HYPOTHESIS REVISITED*
}

\author{
Assaf Razin ${ }^{\dagger}$ and Efraim Sadka
}

\begin{abstract}
Oates reminds us that tax competition among localities in the presence of capital mobility, may lead to inefficiently low tax rates (and benefits). In contrast, the Tiebout paradigm suggests that tax competition yields an efficient outcome, so that there are no gains from tax coordination. This paper demonstrates that when a group of host countries faces an upward supply of migrants, labor and capital income tax rate under competition are higher than under tax coordination, due to a fiscal externality.
\end{abstract}

JEL Classification: F2, H2

Keywords: Tax Competition, Tax Coordination, Fiscal Externality

\section{Introduction}

In this paper we re-examine the race-to-the-bottom hypothesis when several host countries compete for an upward slopping supply of immigrants from the rest of the world. We also revisits the Tiebout paradigm which suggests that the tax competition yields efficient outcomes.

We assume that there is a large enough number of competing host countries, to allow us to treat each host country as a "perfect competitor". The rest of the world serves as a reservoir of migrants for the host countries. That is, the rest of the world provides exogenously given, upward sloping, supply curves of unskilled and skilled immigrants to the host countries.

\footnotetext{
${ }^{*}$ Competent research assistance by Ori Katz is gratefully acknowledged

${ }^{\dagger}$ Tel Aviv University and Cornell University. Email address: razin@post.tau.ac.il

${ }_{\ddagger}^{\ddagger}$ Tel Aviv University. Email address: sadka@post.tau.ac.il
} 
We address the issue whether tax competition among host countries is inefficient, relative to tax coordination, in the presence of migration. Referring to tax competition among localities in the presence of capital mobility, Oates (1972, p. 143) argues that competition may lead to inefficiently low tax rates (and benefits):

"The result of tax competition may well be a tendency toward less than efficient levels of output of local services. In an attempt to keep taxes low to attract business investment, local officials may hold spending below those levels for which marginal benefits equal marginal costs, particularly for those programs that do not offer direct benefits to local business."

Considering international capital mobility, tax-competition among countries, may lead to inefficiently low tax rates and welfare-state benefits because of three mutually reinforcing factors. First, in order to attract mobile factors or prevent their flight, tax rates on them are reduced. Second, the flight of mobile factors from relatively high tax to relatively low tax countries shrinks the tax base in the relatively high tax country. Third, the flight of the mobile factors from relatively high tax to relatively low tax is presumed to reduce the remuneration of the immobile factors, and, consequently, their contribution to the tax revenue. These reinforcing factors reduce tax revenues and, consequently, the generosity of the welfare state.

Our model is somewhat similar to Tiebout's (1956) framework of competition among localities. Tiebout's model features many "utilitytaking" localities, analogous to the perfect competition setup of many "price-taking" agents. Naturally, Tiebout competition yields an efficient outcome. ${ }^{1}$ The Tiebout paradigm considers the allocation of a given population among competing localities. Our model of international taxtransfer and migration competition among host countries deviates from the Tiebout paradigm in that the total population in the host countries and its skill distribution are endogenously determined through migration of various skills. As a result, competition needs not be efficient. We therefore study also the policies that ensue through coordination among the host countries and compare them to the competition policies.

Typically, models of tax competition among host countries consider a given system of collective decision making. For instance, many models assume that policy is determined by maximizing some social welfare

\footnotetext{
${ }^{1}$ See Wilson (1999), and Bovenberg et al (2003), for a comprehensive surveys of theories on tax competion. Razin and Sadka (1991) who consider tax competition among "price taking" small countries, in the presence of capital mobility, show that there are no gains from tax coordination. Mendoza and Tesar (2005), and Sorensen (2001), calibrate tax competition general equilibrium models to Europe.
} 
function. Another possibility is decision by majority voting . In this paper, we adopt the second approach. Broader analysis of the interactions between the welfare state fiscal stance and migration is in Razin, Sadka and Suwankiri (2011).

The organization of the paper is as follows. Section 2 reviews evidence on the fiscal burden of migration. Section 3 develops a parsimonious model of tax-migration competition. Section 4 extends the model to allow tax coordination. Section 5 compares (via numerical simulations) the set of policies that ensue under competition and under coordination. Section 6 concludes.

\section{Evidence on the Fiscal Burden of Migration}

To motivate, it is worthwhile to review some evidence on the fiscal aspects of migration and on native born attitudes toward immigration, before we develop the tax competition model.

In 1997 the U.S. National Research Council sponsored a study on the overall fiscal impact of immigration into the U.S.; see Smith and Edmonston (1997). The study looks comprehensibly at all layers of government (federal, state, and local), all programs (benefits), and all types of taxes. For each cohort, defined by age of arrival to the U.S., the benefits (cash or in kind) received by migrants over their own lifetimes and the lifetimes of their first-generation descendents were projected. These benefits include Medicare, Medicaid, Supplementary Security Income (SSI), Aid

for Families with Dependent Children (AFDC), food stamps, Old Age, Survivors, and Disability Insurance (OASDI), etc. Similarly, taxes paid directly by migrants and the incidence on migrants of other taxes (such as corporate taxes) were also projected for the lifetimes of the migrants and their first-generation descendents. Accordingly, the net fiscal burden was projected and discounted to the present. In this way, the net fiscal burden for each age cohort of migrants was calculated in present value terms. Within each age cohort, these calculations were disaggregated according to three educational levels: Less than high school education, high school education, and more than high school education.

Indeed the findings suggest that migrants with less than high school education are typically a net fiscal burden that can reach as high as approximately US- $\$ 100,000$ in present value, when the immigrants' age on arrival is between 20-30 years. See also the related analysis of Auerbach and Oreopoulos (1999).

Following the recent enlargement of the European Union to 27 countries, only three members of the EU-15 (the UK, Sweden and Ireland) allowed free access for residents of the accession countries to their na- 
tional labor markets, in the year of the first enlargement, 2004. The other members of the EU-15 took advantage of the clause that allows for restricted labor markets for a transitional period of up to seven years. Focusing on the UK and the A8 countries, Dustmann at al (2009) bring evidence of no welfare migration. The average age of the A8 migrants during the period 2004-2008 is 25.8 years, considerably lower than the native U.K. average age (38.7 years). The A 8 migrants are also better educated than the native-born. For instance, the percentage of those The A8 countries are the first eight accession countries (Czech Republic, Estonia, Hungary, Latvia, Lithuania, Slovenia and Poland.) More accurately, the said period extends from the second quarter of 2004 through the first quarter of 2009 that left full-time education at the age of 21 years or later is 35.5 among the A8 migrants, compared to only 17.1 among the U.K. natives. Another indication that the migration is not predominantly driven by welfare motives is the higher employment rate of the A8 migrants $(83.1 \%)$ relative to the U.K. natives (78.9\%). Furthermore, for the same period, the contribution of the A8 migrants to government revenues far exceeded the government expenditures attributed to them. A recent study by Barbone et al (2009), based on the 2006 European Union Survey of Income and Living conditions, finds that migrants from the accession countries constitute only 1-2 percent of the total population in the pre-enlargement EU countries (excluding Germany and Luxemburg); by comparison, about 6 percent of the population in the latter EU countries were born outside the enlarged EU. The small share of migrants from the accession countries is, of course, not surprising in view of the restrictions imposed on migration from the accession countries to the EU-15 before the enlargement and during the transition period after the enlargement.

The study shows also that there is, as expected, a positive correlation between the net current taxes (that is, taxes paid less benefits received) of migrants from all source countries and their education level. Hainmeueller and Hiscox (2010), using survey data in the US, find two critical economic concerns that appear to generate anti-immigrant sentiments among voters: concerns about labor-market competition, and concerns about the fiscal burden on public services. Not unexpectedly, employing opinion surveys, Hanson et al (2007) bring evidence that in the United States native residents of states which provide generous benefits- to migrants also prefer to reduce the number of migrants. Furthermore, the opposition is stronger among higher income groups. Similarly, Hanson et al (2009), again employing opinion surveys, find for the United States that native-born residents of states with a high share of unskilled migrants, among the migrants population, prefer to restrict 
in migration; whereas native-born residents of states with a high share of skilled migrants among the migrant population are less likely to favor restricting migration6. Indeed, developed economies do attempt to sort out immigrants by skills (see, for instance, Bhagwati and Gordon (2009)). Australia and Canada employ a point system based on selected immigrants' characteristics. The U.S. employs explicit preference for professional, technical and kindred immigrants under the so-called third-preference quota. Jasso and Rosenzweig (2009) find that both the Australian and American selection mechanisms are effective in sorting out the skilled migrants, and produce essentially similar outcomes despite of their different legal characteristics. ${ }^{2}$

\section{Analytical Framework}

Consider $\mathrm{n}$ identical host countries engaged in competition over migrants, skilled and unskilled, from the rest of the world. The model incorporates two channels through which native households are effected by migration: the wage channel and the fiscal channel. The former relates to the fact that skilled (unskilled) individuals favour unskilled (skilled) migration since it boosts their wage. The latter relates to the fact that all migrants contribute to the financing of the public good through a proportional income tax (on both labor and capital). ${ }^{3}$

\subsection{Representative Host Country}

A representative host country produces a single good by employing two labor inputs, skilled and unskilled, and capital according to a CobbDouglas production function,

$$
Y=A K^{\beta} L_{s}^{(1 \square \beta) \alpha} L_{u}^{(1 \square \beta)(1 \square \alpha)}, 0<\alpha<1,0<\beta<1,
$$

where, $Y$ is GDP, $A$ denotes a Hicks-neutral productivity parameter, and $L_{i}$ denotes the input of labor of skill level $i$, where $i=s, u$ for skilled and unskilled, respectively, $\mathrm{K}$ denotes the input of capital, $\beta$ denotes the share of capital, and $\alpha$ denotes the share of skilled labor in the total share, $1 \square \beta$, of labor.

\footnotetext{
${ }^{2}$ See also Boeri, Hanson, and McCormick (2002); See also Mayda (2006)

${ }^{3}$ There exists a body of literature which emphasizes the importance of both channels. The wage channel is analayzed in, for instance, Ortega (2005) and olso partly in Kemnitz (2002). Ortega goes even further than this paper and allows migrants to become part of the electorate in the period after migration has taken place.
} 
The competitive wages of skilled and unskilled labor are, respectively,

$$
\begin{gathered}
w_{s}=(1 \square \beta) \alpha Y / L_{s} \\
w_{u}=(1 \square \beta)(1 \square \alpha) Y / L_{u} .
\end{gathered}
$$

Note that the abundance of skilled labor raises the wage of the unskilled, whereas abundance of unskilled labor raises the wage of the skilled.

Aggregate labor supply, for skilled and unskilled workers, respectively, is given by:

$$
\begin{gathered}
L_{s}=\left(S+m_{s}\right) l_{s} \\
L_{u}=\left(1 \square S+m_{u}\right) l_{u} .
\end{gathered}
$$

There is a continuum of workers, where the number of native-born is normalized to $1 ; S$ denotes the share of native born skilled in the total native-born labor supply; $m_{s}$ denotes the number of skilled migrants; $m_{u}$ denotes the total number of unskilled migrants; and $l_{i}$ is the labor supply of an individual with skill level $i \in\{s, u\}$

Total population (native born and migrants) is as follows

$$
N=1+m_{u}+m_{s} .
$$

The rental price of capital is given by the marginal productivity condition:

$$
r=\beta Y / K
$$

(we assume for simplicity that capital does not depreciate). A skilled individual holds a stock of capital, $\bar{K}_{s}$, which is larger than the stock of capital, $\bar{K}_{u}$, which is held by an unskilled individual; that is $\bar{K}_{s}>\bar{K}_{u}$, so that the skilled is unambiguously richer than the unskilled. An individual can rent her capital either at home or at the other host countries. Thus, the total stock of capital owned by residents, $S \bar{K}_{s}+(1 \square S) \bar{K}_{u}$ (assuming that migrants own no capital), does not have to equal $\mathrm{K}$, the total inputs of capital. Capital taxation, if any, is levied according to the source principle, according to which each country taxes only the capital employed in that country ${ }^{4}$. Denote the net-of-tax rental price of capital

\footnotetext{
${ }^{4}$ We do not consider residence-based taxation of capital, according to which each country taxes its residents on all the capital they own, irrespective of its location. In this case the capital tax policy does not change the capital tax base. Thus, tax competition over mobile capital does not affect tax policy. We therefore do not consider residence-based taxation. Also, residence-based taxation is not readily enforceable.
} 
in all other host countries by $\bar{r}$. Then, the residents of the representative host country must enjoy the same net-of-tax rental price at home, that is:

$$
\left(1 \square \tau_{K}\right) r=\bar{r}
$$

where $\tau_{K}$ is the tax rate on capital employed by our representative host country.

We specify a simple welfare-state system in which there is a dual tax system: a tax at the rate $\tau_{L}$ on labor income and a tax at the rate $\tau_{K}$ on capital income. We allow for different rates of taxation of labor and capital in order to examine the effects of migration and capital mobility separately on capital and labor taxation. The revenues from all taxes are redistributed equally to all residents (native born and migrants alike) as a demogrant, $b$, per capita. The demogrant may capture not only a cash transfer but also outlays on public services such as education, health, and other provisions, that benefit all workers, regardless of their contribution to the finances of the system. Thus, b is not necessarily a perfect substitute to private consumption.

The government budget constraint is given by:

$$
b=\frac{\tau_{K} r K+\tau_{L}\left(w_{s} L_{s}+w_{u} L_{u}\right)}{N} .
$$

Note that we assume that migrants are fully entitled to the welfare state system. That is, they pay the tax rate $\tau_{L}$ on their labor income (they own no capital) and receive the benefit b. The two types of individuals share the same utility function,

$$
u=c \square \frac{\varepsilon}{1+\varepsilon} l^{\frac{1+\varepsilon}{\varepsilon}}+\ln (b),
$$

where $c$ denotes consumption and $\varepsilon>0$, in the labor supply elasticity. Recall that we interpret b not just as a pure cash transfer, but rather as some public service that creates a utility of $\ln (b)^{5}$.

The budget constraint of an individual with skill level $i$ is

$$
c_{i}=\left(1 \square \tau_{L}\right) l_{i} w_{i}+(1+\bar{r}) \bar{K}_{i}, i \in\{s, u\}
$$

\footnotetext{
${ }^{5}$ This interpretation of $b$ and the specification of the utility derived from it ensure that everyone, including the rich, opts for some positive level of $\mathrm{b}$ and is willing to support some taxation
} 
Note that an individual earns a net-of-tax rental price of $\bar{r}$ on all the stock of capital she owns, no matter in which country it is employed.

Individual utility-maximization yields the following labor supply equation

$$
l_{i}=\left(\left(1 \square \tau_{L}\right) w_{i}\right)^{\varepsilon}, i \in\{s, u\}
$$

The indirect utility function of an individual of skill level $i \in\{s, u\}$ is given by

$$
V_{i}(\tau, b)=\ln (b)+\frac{1}{1+\varepsilon}\left((1 \square \tau) w_{i}\right)^{1+\varepsilon}+(1+\bar{r}) \bar{K}_{i}, i \in\{s, u\} .
$$

We also assume that

$$
\frac{\alpha\left(1 \square S+m_{u}\right)}{(1 \square \alpha)\left(S+m_{s}\right)}>1,
$$

which ensures that the wage of the skilled always exceeds the wage of the unskilled $\left(w_{s}>w_{u}\right)$.

\subsection{Supply of Migrants}

We assume that there is free migration according to an exogenously given upward supply of migrants of each skill type from the rest of the world to all host countries ${ }^{6}$. Specifically, the number of migrants of each skill type that wish to emigrate to the host countries rises with the level of utility (well-being) that they will enjoy in the host countries. A possible interpretation for this upward supply is as follows. For each skill type there is a heterogeneity of some migration cost (due to some individual characteristics such as age, family size, portability of pensions, etc.). This cost generates a heterogeneity of reservation utilities, giving rise to an upward sloping supply of migrants. We denote the supply function of skill $i \in\{s, u\}$ by

$$
N_{i}=f_{i}\left(V_{i}\right)
$$

where $N_{i}$ is the number of migrants of skill type $i$ and $V_{i}$ is the level of utility enjoyed in the host counties, $i \in\{s, u\}$.

\footnotetext{
${ }^{6}$ In Razin and Sadka (2010) we consider a host-source country contest and endogenise the supply of migrants to a single host country, abstracting from competition among many host countries over the same pool of migrants. Here we consider an exogenous supply of immigrants, as we focus on competition among many host countries.
} 
We assume that would-be migrants are indifferent with respect to the identity of the would-be host country. All they care about is the level of utility they will enjoy. Therefore, in equilibrium, the utility enjoyed by migrants of each skill type is the same in all host countries. Denote this equilibrium cutoff utility level by $\bar{V}_{i}, i \in\{s, u\}$.

Being small enough, each host country takes these cutoff utility levels as given for her. That is, each host country behaves as a "utility - taker", in analogy to the "price taking" behavior of each agent in perfectly competitive market.

\subsection{Fiscal Policy Choice}

A representative host country determines its fiscal policy by majority voting among the native born. For concreteness, we describe in details the case where the native-born skilled form the majority, that is $S>0.5$ (the other case is specified similarly). Thus, the fiscal policy variables, $\tau_{L}, \tau_{K}$ and $b$, are chosen so as to maximize the indirect utility of the skilled (given in equation (11)), subject to the government budget constraint (given in equation (7)), and to the free migration constraints:

$$
V_{s}\left(\tau_{L}, \tau_{K}, b\right) \square(1+\bar{r}) \bar{K}_{s}=\bar{V}_{s},
$$

and

$$
V_{u}\left(\tau_{L}, \tau_{K}, b\right) \square(1+\bar{r}) \bar{K}_{u}=\bar{V}_{u},
$$

assuming that the migrants have the same preferences as the nativeborn, and recalling that migrants own no capital.

In determining their policy, the government takes also into account that $w_{i}, l_{i}, L_{i}, r, K, N, Y, m_{s}$ and $m_{u}$ are determined in equilibrium by equations (1)-(6), and (10).

Note that in setting the optimal fiscal policy, a representative host country takes the migrants cutoff utility levels, $\bar{V}_{s}$ and $\bar{V}_{u}$, as given, and also takes the net of tax return to capital, $\bar{r}$, as given. Denote by an asterisk $(*)$ the levels of the economic variables that ensue with optimal fiscal policy.

\subsection{Symmetric Tax - Competition Equilibrium}

Each one of the $\mathrm{n}$ identical host countries admits $m_{s}^{*}$ skilled migrants and $m_{u}^{*}$ unskilled migrants. Thus, the aggregate demand for skilled and unskilled migrants is $n m_{s}^{*}$ and $n m_{u}^{*}$. Therefore, the cutoff utilities 
enjoyed by migrants, $\bar{V}_{s}$ and $\bar{V}_{u}$, are determined in a symmetric Nashequilibrium, so as to equate supply and demand: ${ }^{7}$

$$
n m_{s}^{*}=f_{s}\left(\bar{V}_{s}\right)
$$

and

$$
n m_{u}^{*}=f_{u}\left(\bar{V}_{u}\right)
$$

Also, the world wide net-of-tax rental price of capital, $\bar{r}$, is determined so as to equate world demand for capital, $n K^{*}$, to world supply, $n\left(S \bar{K}_{s}+(1 \square S) \bar{K}_{u}\right)$, that is:

$$
K^{*}=S \bar{K}_{s}+(1 \square S) \bar{K}_{u}
$$

\section{Fiscal Coordination}

So far we assumed that the host countries compete with each other with respect to the volume and the skill-composition of migrants, and for capital. Presumably, an unskilled median voter opts to admit skilled migrants, for two reasons: First, such migrants are net contributors to the finances of the welfare state, that is the tax that each one pays (namely, $\tau_{L} w_{s} l_{s}$ ) exceeds the benefit she receives (namely, b). Second, skilled migrants raise the wage of the unskilled. On the other hand, a skilled median voter may opt for both types of migrants. Unskilled migration raises the wage of the skilled but imposes a fiscal burden on the welfare state. Skilled migration lowers the wage of the skilled but contributes positively to the finances of the welfare state. Thus, the volume and skill-composition of migration to each one of the $\mathrm{n}$ identical host countries are determined in a general, uncoordinated competitive equilibrium.

An alternative, albeit difficult to sustain, is for the host countries to coordinate their fiscal policy so as to maximize the utility of their decisive median voter ${ }^{8}$. Naturally, this coordination comes at the expense of the

\footnotetext{
${ }^{7}$ Because of the constant returns-to-scale assumption, one may think that there is no unique determination of the size of internatinal floes (of labor and capital). But the upward aggregate supply of migrants and the fixed aggregate stock of capital insure uniqueness in equilibrium (like the case of many firms with constan-returnsto-scale technologies in industry equilibrium).

${ }^{8}$ This coordination is among the host countries only, unlike some other coordination arrangements (such as under the auspices of the WTO) that refer to both exports and imports of goods and services. The coordination discussed here may be relevant to unions of countries with independent tax policies such as the EU which can coordinate a uniform migration and tax policy towards the rest of the world (as the U.S.A does).
} 
migrants.

In a coordinated-policy regime the cutoff utilities, $\bar{V}_{s}$ and $\bar{V}_{u}$, are also controlled by the host countries, taking into account that migration takes place according to the migration equations (14) and (15). They set also the common (by symmetry) tax rate on capital, and consequently $\bar{r}$, taking into account the capital resource constraint (18).

\section{Competition vs. Coordination: Is there a Race to the Bottom}

Evidently, coordination can only improve the well-being of the skilled which is in power (recall that we consider for concreteness the case $\mathrm{S}>$ 0.5) compared to its well-being under competition.

In this section we compare also the tax policies that arouse under competition and under coordination. Specifically, we ask whether competition can lead to "a race to the bottom" in the sense that it yields lower tax rates and welfare-state benefits, relative to the coordination regime. We carry this comparison via numerical simulations. In the appendix we attempt to provide a rough sketch of how an analytic analysis may proceed.

Figure 1 depicts the results of numerical simulations. In panel (a) we plots the labor and capital tax rates in the coordination and competition regimes on the vertical axis and the host country productivity on the horizontal axis.

[Insert figure 1 here]

Parameters: $\alpha=0.7 ; \beta=0.33 ; \varepsilon=0.1 ; S=0.6 ; A=6.2$ to $7.2 ; \bar{K}_{s}$ $=1 ; \bar{K}_{u}=0.5 ; n=1 ; B=1.5 ; f_{s}\left(\bar{V}_{s}\right)=f_{u}\left(\bar{V}_{u}\right)=(\bar{V} / B)^{B}$

The figure clearly refutes the race-to-the-bottom hypothesis for both the labor and the capital income taxes: the taxes are lower in the coordinated regime than in the competitive regime.

The rationale for this somewhat suprising results seems to be quite basic: a fiscal externalitiy associated with the volume of migration.

There are gains and losses brought about by migration. A host country has an infra-marginal gain from migration because of the diminishing productivity of labor for a given stock of capital. On the other hand, the native-born population shares with migrants the tax collected from capital income (recall that migrants have no capital): the transfer $b$ that the migrants receive in not financed fully by their labor income tax. That 
is, the capital tax revenues paid by the native-born population "leak" also to the migrants ${ }^{9}$. Each host country in a competitive regime evidently balances on the margin the gains and losses from migration. In doing so, each country takes the well-being of the migrants as given (see equation (14) - (15)). It ignores the fact that a tax-migration policy that admits an extra migrant raises the well-being that must be accorded to migrants by all host countries, in order to elicit the migrant to come in. As a results, it offers migrants too high level of $b$, levies too high taxes, and admits too many migrants. Indeed, figure 1(b) shows that the number of both types of migrants is higher in the competitive than in the coordinated regime. Note also that tax rates on capital income are lower than tax rates on labor income. This is a way that native born who is endowed with capital take advantage of the migrants, who have no capital.

Figure 2 shows similar results for the case where the unskilled form the major: tax rates are higher and the number of migrants is higher in the competitive than in the coordinated regime.

[Insert figure 2 here]

Parameters: $\alpha=0.7 ; \beta=0.33 ; \varepsilon=0.1 ; S=0.4 ; A=6.2$ to $7.2 ; \bar{K}_{s}$ $=1 ; \bar{K}_{u}=0.5 ; n=1 ; B=1.5 ; f_{s}\left(\bar{V}_{s}\right)=f_{u}\left(\bar{V}_{u}\right)=(\bar{V} / B)^{B}$

\section{Conclusion}

The literature on tax competition with free capital mobility cites several reasons for the race-to-the-bottom hypothesis in the sense that tax competition may yield significantly lower tax rates than tax coordination. With a fixed (exogenously given) population that can move from one fiscal jurisdiction to another, the Tiebout paradigm suggests that tax competition among these jurisdictions yields an efficient outcome, so that there are no gains from tax coordination. This paper provides some support to the Tiebout hypothesis. It suggests that when a group of host countries faces an upward supply of immigrants, tax competition does not indeed lead to a race to the bottom; competition may lead to higher taxes than coordination. We identify a fiscal externality (fiscal leakage) that causes tax rates (on both labor and capital), and the volume of migration (of both skill types), to be higher in the competitive regime than in the coordinated regime.

\footnotetext{
${ }^{9}$ Fiscal leakage effects are analyzed in Razin and Sadka (2001)
} 


\section{Appendix}

In order to shed some light on the analytics of the results consider a very simple model, with only one type of migrants and suppose that the government owns all the capital. Note that the transfer $(b)$ depends on the labor $\operatorname{tax}(\tau)$ and the number of migrants $(m)$. Denote then the indirect utility function by $V(\tau, m)$. In a competitive (uncoordinated) regime each government solves the following optimization program:

$\max _{\{\tau, m\}} \mathrm{V}(\tau, m)$

s.t. $V(\tau, m) \geq \bar{V}$

where $\bar{V}$ is the utility level that must be enjoyed by the migrants and is considered to be exogenously given by each government. At equilibrium we have $n m=f(\bar{V})$, where $f$ is the supply function of migrants. thus, a competitive (uncoordinated) equilibrium is given by
(A1) $V_{\tau}+\lambda V_{\tau}=0$
(A2) $V_{m}+\lambda V_{m}=0$
(A3) $\bar{V}=g(\mathrm{~nm})$

where $\lambda$ is a Lagrange multiplier and $g$ is the inverse of $f$. Note that there is an upward sloping supply of migrants, so that $g^{\prime}>0$. Note also that (A1) and (A2) imply that

(A4) $V_{\tau}=V_{m}=0$

In a coordinated regime, the optimal policy is a solution to the following regime:

$\max _{\{\tau, m\}} \mathrm{V}(\tau, m)$

s.t. $V(\tau, m) \geq g(\tau, m)$

Thus, the optimal policy is characterized by

(A5) $V_{\tau}+\theta V_{\tau}=0$

(A6) $V_{m}+\theta V_{m} \square \theta g_{m}^{\prime}=0$

We can then conclude that

(A7) $V_{\tau}=0$

(A8) $V_{m}>0$

(Recall that $g^{\prime}>0$ )

Denote the competitive equilibrium levels of $\tau$ and $m$ by $\tau^{*}$ and $m^{*}$, respectively. At $m^{*}$, we have $V_{m}=0$ (see equation (A4)). Suppose that $V$ first rises with $m$ until it peaks at the competitive level of $m$ (which is $m^{*}$ ), and then declines. Hence, $V_{m}>0$ for $m \leq m^{*}$. Therefore, it follows from (A8) that the coordinated level of $m$ is below $m^{*}$. That is, there are fewer migrants in the coordinated regime than in the competitive (unregulated) regime.

Moving from the coordinated to the competitive regime presumably lowers $V_{\tau}$. This is because $m$ is higher in the competitive regime and hence, due to the "fiscal leakage" effect, $V_{\tau}$ falls below zero. In order 
to set $V_{\tau}$ back to zero at the competitive regime, $\tau$ must fall, if $V_{\tau \tau}$ is negative. In this case, the tax rate is lower in the competitive than in the coordination regime.

\section{References}

\section{References}

[1] Auerbach, A. and P. Oreopoulos (1999), "Analyzing the Economic Impact of U.S. Immigration," American Economic Review Papers and Proceedings, 89(2), 176-180.

[2] Barbone, Luca, Bontch-Osmolovsky, Misha and Salman Zaidi (2009), "The Foreign-Born Population in the European Union and its Contribution to National Tax and Benefit Systems" Policy Research Working Paper, the World Bank (April).

[3] Bhagwati, Jagdish and Gordon Hanson (2009), editors, Skilled Immigration Today: Prospects, Problems and Policies, Oxford University Press.

[4] Boeri, Tito, Gordon Howard Hanson and Barry McCormick (2002), Immigration Policy and the Welfare System: A Report for the Fondazione Rodolfo Debenedetti, Oxford University Press.

[5] Boeri, T., G. Hanson and B. McCormick (eds., 2002), Immigration policy and the welfare system, Oxford University Press, Oxford.

[6] Bovenberg, Lans, Sijbern Cnossen and Ruud de Mooij, "Introduction: Tax Coordination, in the European Union," International Tax and Public Finance, 10, 619-624, 2003

[7] Dustmann, C., Frattini, T. \& Halls, C. (2009), "Assessing the Fiscal Costs and Benefits of A8 Migration to the UK", CReAM Discussion Paper No. 18/09

[8] Hainmueller, Jens, and Michael J. Hiscox (2010), "Attitudes toward Highly Skilled and Low-skilled Immigration: Evidence from a Survey Experiment" American Political Science Review, 104, no 1, February, 61-84

[9] Hanson, Gordon H. (2008), "The Economic Consequence of the International Migration of Labor," NBER Working Paper No. 14490 , November.

[10] Hanson, Gordon, Scheve, Kenneth, and Matthew J. Slaughter (2009) "Individual Preferences over High-Skilled Immigration in the United States," in Bhagwati, Jagdish and Gordon Hanson, editors, Skilled Immigration Today: Prospects, Problems and Policies, Oxford University Press.

[11] Hanson, Gordon, Scheve Kenneth and Matthew J. Slaughter (2007), "Public Finance and Individual Preferences over Globalization 
Strategies" Economics and Politics, 19(1), March, 1-33

[12] Jasso, Guillermina and Mark R. Rosenzweig (2009) "Selection Criteria and the Skill Composition of Immigrants: A Comparative Analysis of Australian and U.S. Employment Immigration," in Bhagwati, Jagdish and Gordon Hanson, editors, Skilled Immigration Today: Prospects, Problems and Policies, Oxford University Press.

[13] Kemnitz, A. (2002), "On the political economy of low-skilled immigration and the welfare state", International Tax and Public Finance 9, 423 - 434 .

[14] Mayda, Anna Maria (2006), "Who Is Against Immigration? A Cross-Country Investigation of Individual Attitudes toward Immigrants", Review of Economics and Statistics.

[15] Mendoza, Enrique and Linda Tesar (2005), "Why Hasn't Tax Competition Triggered a Race To The Bottom? Some Quantitive Lessons from the EU", Journal of Monetary Economics, 52 (1), 163-204

[16] Oates, Wallace E. (1972), Fiscal Federalism. New York: Harcourt Brace Jovanovich.

[17] Ortega, F. (2005), Immigration Quotas and Skill Upgrading," Journal of Public Economics, 89(9-10), 1841-1863.

[18] Razin, Assaf an Efraim Sadka (1991), "International Tax Competition and Gains from Tax Harmonization", Economics Letters 37, 69-76.

[19] Razin, Assaf an Efraim Sadka (2001), "Labor, Capital and Finance: International Flows", Cmbridge University Press

[20] Razin, Assaf an Efraim Sadka (2010), "Fiscal and Migration Competition", NBER working paper 16224 .

[21] Razin, Assaf, Efraim Sadka, and Benjarong Suwankiri, (2011), Migration and the Welfare State: Political-Economy Policy Formation, MIT Press, (October), Cambridge, Massachusetts, USA.

[22] Sørensen, Peter Birch 2001. "Tax coordination in the European Union: What are the issues? University of Copenhagen, mimeo.

[23] Smith, James P. and Barry Edmouston, editors, (1997), The New Americans: Economic, Demographic and Fiscal Effects of Immigration, National Academy Press, Washington, D.C

[24] Tiebout, Charles, "A Pure Theory of Local Expenditures," Journal of Political Economy, 64, 1956. 


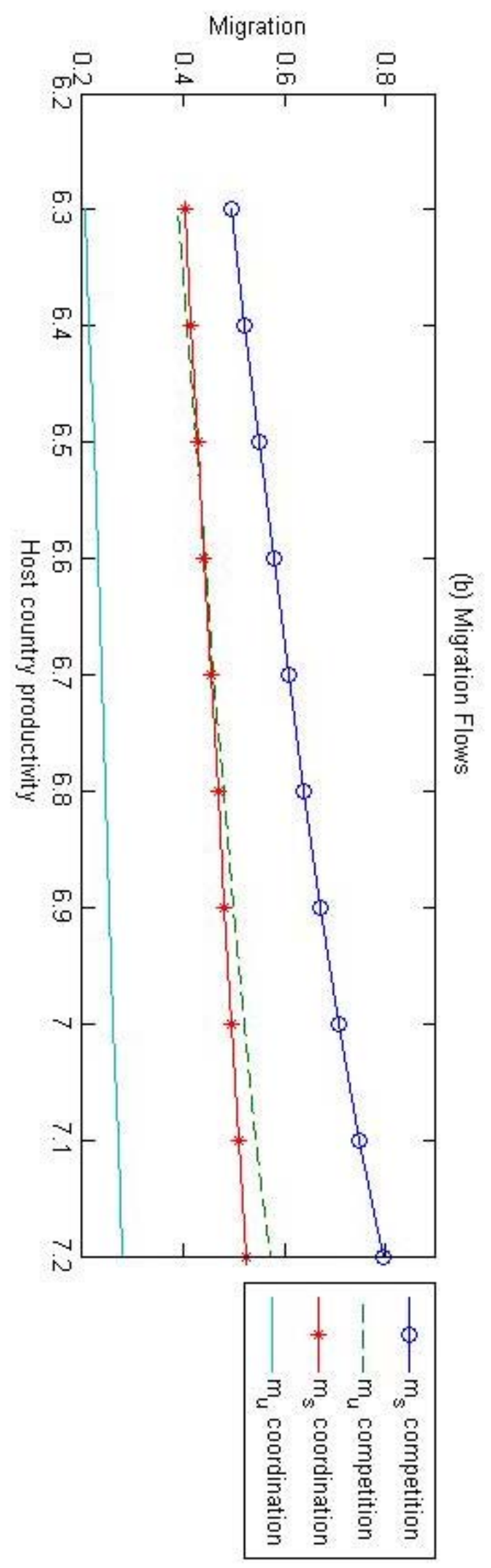

Tax Rate

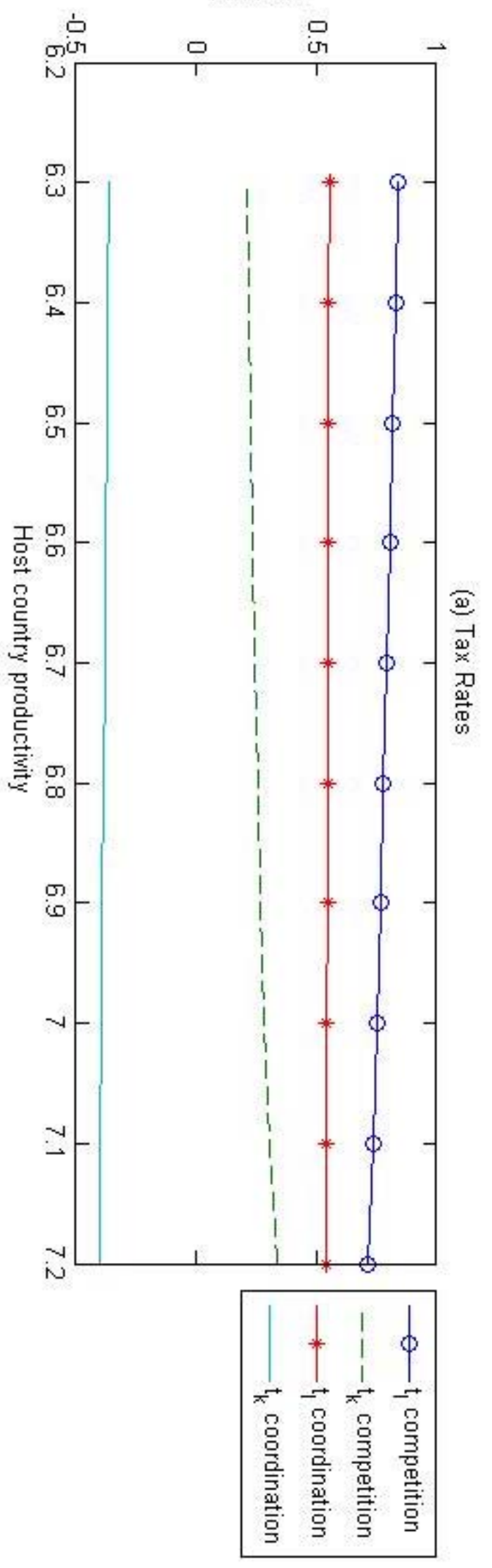



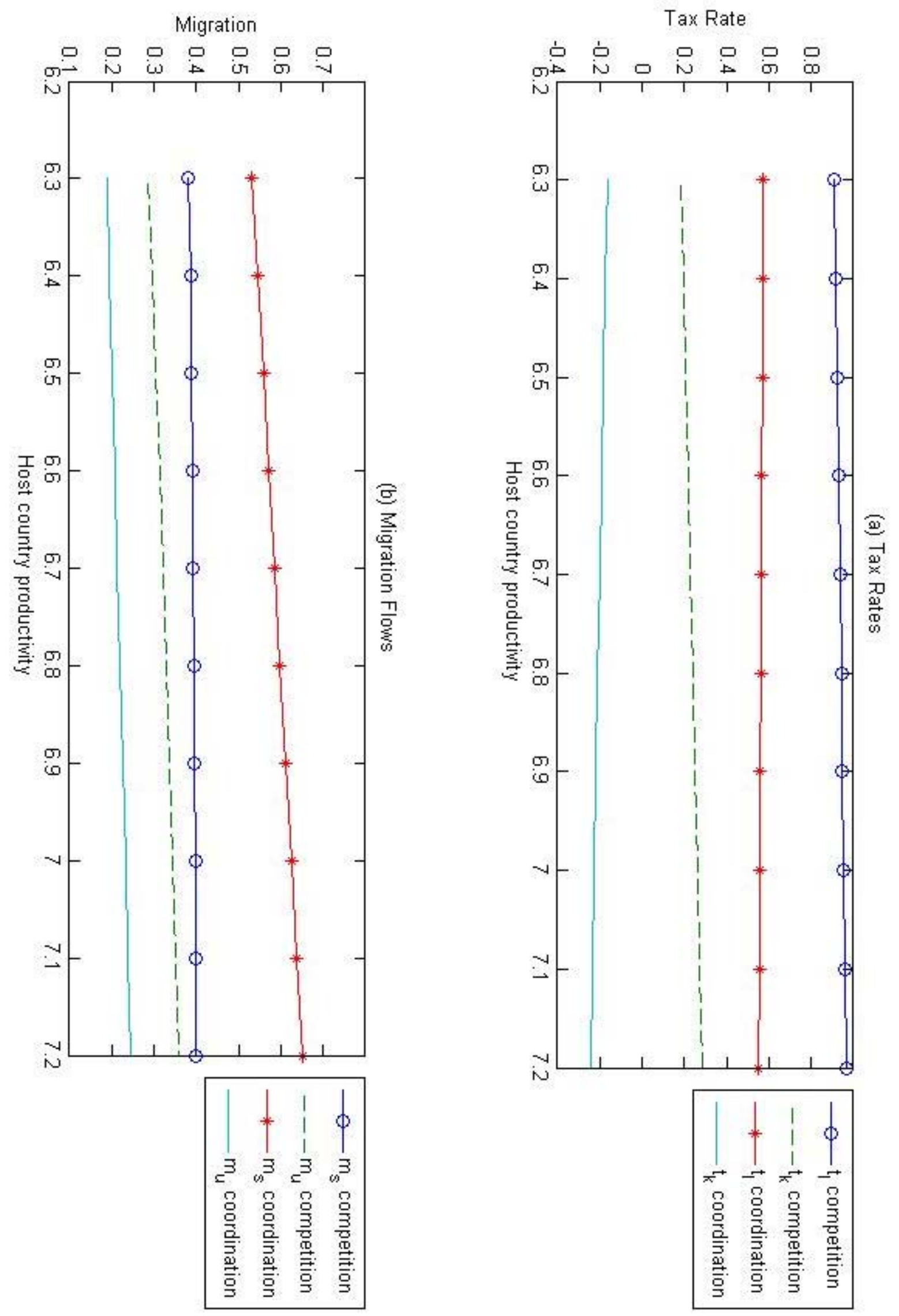